УДК 780. 647.2 (045)

ORCID 0000-0002-9962-3069

\title{
Тишик Вадим
}

Харківський національний університет мистещтв

ім. І. П. Котляревського

\section{ФОРМУВАННЯ СИСТЕМИ ПРОФЕСІЙНИХ НАВИЧОК БАЯНІСТА (НА ПРИКЛАДІ «АЛЬБОМУ ДЛЯ ДІТЕЙ ТА ЮНАЦТВА» В. ВЛАСОВА)}

Тищик В. Формування системи професійних навичок баяніста (на прикладі «Альбому для дітей та юнацтва» В. Власова. Творчість Віктора Власова, одного з найяскравіших представників сучасної баянної школи України, $\epsilon$ особливою сторінкою музичної культури, зокрема, баянного мистецтва для дітей. Своєю творчістю В. Власов впроваджує у дитячу музику нові ідеї та прийоми виконавської майстерності, які увиразнюють яскраві художні образи. Він застосовує новітні композиторські техніки, приділяє увагу нетрадиційним прийомам звукоутворення. Завдяки такому розмаїттю твори В. Власова слугують професійному вихованню дітей і орієнтиром для тих, хто працює у сфері дитячої баянної музики. Перед музикознавцями стоїть важливе завдання - узагальнити критерії системи професійних навичок юного баяніста, втілені у творчості майстра.

Ключові слова: українська баянна музика, альбом для дітей та юнацтва, сучасне баянне виконавство, композиторський стиль В. Власова.

Тыщик В. Формирование системи профессиональных навыков баяниста (на примере «Альбома для детей и юношества») В. Власова Творчество Виктора Власова, одного из самых ярких представителей современной баянной школы является особой страницей музыкальной культуры Украины, в частности, баянного искусства для детей. Своим творчеством В. Власов внедряет в отечественную детскую музыку новые идеи и приемы композиторской техники, которые воплощают яркие художественные образы, уделяет внимание новейшим нетрадиционным приемам звукообразования. Благодаря жанрово-стилистическому разнообразию произведения В. Власова служат воспитанию детей и ориентиром для тех, кто работает в сфере детской баянной музыки. Перед музыковедам стоит важная задача - обобщить основные критерии системы профессиональных навыков юного баяниста, 
авоплощенніе в творчестве мастера.

Ключевые слова: украинская баянная музыка, альбом для детей и юношества, современное баянное исполнительство, композиторский стиль В. Власова.

\section{Tyshchyk V. The system formation of professional accordionist's skills on the} example of V. Vlasov «Album for children and youth» Viktor Vlasov is one of the brightest representatives of Ukrainian button accordion school, and his work is a special page in the musical culture of Ukraine and a significant component of the button accordion art for children. By his work V. Vlasov implements, new ideas and techniques of performing skills that rely on bright artistic images in the native children's music, and also applies the means of composition techniques that appear in contemporary button accordion art and he pays attention to the latest unconventional methods of sound making. Due to this variety, V. Vlasov's works have no only their main task - the education of children, but also it is a guideline for other composers.

Music scholars, who study the work of Ukrainian composer-accordionist V. Vlasov, have the important task to give a proper assessment of work in general, and summarize the basic criteria of his approach to the formation of the system of young accordionist's professional skills.

Children's music of button accordion of Ukrainian authors is a significant amount of works for young performers. Although the history of button accordion performance and pedagogy in comparison with other musical instruments is very short, it can be confirmed of the formation of certain schools of button accordion craftsmanship, including the author's schools, one of which includes the original work of V. Vlasov. In Ukraine, the period of children's music of button accordion development was synchronized with the formation of a professional button accordion music in general. Beginning from the second half of the twentieth century composers-accordionists made a huge contribution to the musical heritage, including for children. At the same time, information about this stage of musical culture is still poorly explored, the potential of the Ukrainian children's music of button accordion is not sufficiently defined, the information about collections of plays for children and young people of Ukrainian composers is not generalized or systematized. Ukrainian music for children encompasses a multitude of individual composer styles (from V. Kosenko, M. Lysenko, I. Shamo to contemporary authors such as A. Gaidenko, V. Vlasov, P. Gubanov, O. Shmykov, B. Myronchuk and many others. V. Vlasov definitely can be considered composers with a brightly individually creative writing. All composer's musical creativity is original and is closely connected with Ukrainian and world classics using authentic 
folklore, with an appeal to modern pop and jazz genres. He is the author of many works for button accordion which are as complicated, oriented on high level masters as works for beginners. V. Vlasov's «Album for Children and Youth» has become an important achievement in the field of button accordion art. The cycle of V. Vlasov includes 45 different-colored music pieces; they are not connected with a plot-thematic line, because each music piece has its musical and artistic content. In addition, the music pieces are grouped into five notebooks in accordance with the general plan and a clear pedagogical task. In the first two notebooks of the album («Album of the first-graders», «At a visit to a fairy tale «), the world of a modern child is developed very clearly in the tradition of children's album from such composers as R. Schumann and P. Chaikovsky to S. Prokofiev and B. Bartok. In the notebook «Folk tunes» which includes folk treats, V. Vlasov managed to cover folk leaks of different regions of Ukraine. The music pieces of the last notebook («Variety-jazz plays») are based on modern jazz language. Researchers more often pay attention to the listed notebooks. This article focuses on the central book of the album - «Chamber Plays». Three sonatas at the beginning of this notebook are perceived as a microcycle where the specificity of sonat thinking is consistently revealed and the artistic and technical tasks for the artist are gradually becoming more complex. The first music piece is a miniature «Sonatyna» of F-dur of early classical type, but even in the summary presentation the thematic contrast is already presented and the functional and logical side of the sonata form is implemented. The second «Sonatyna» D-dur meets the examples of Vienna classics - the thematic is based on the original contrast, there is already a motive comparison in a small development. The third «Sonatyna» $\mathrm{C}$-dur is the most difficult task for performance; it relies on a complex of expressive means corresponding to the music of the 20th century - the toccata-basis of the themes, a complex harmonious language. Thus, three sonatas are a short «summary» of the genre for button accordionists at beginner level. The study of these sonatas is important for assimilating the most complex musical structure. The following music plieces are devoted to other genres, where the author focuses on the transformation of stylistic features. The romantic type of «Serenade» focused on J. Field's nocturnes has such features as intricacy, expressiveness, sensuality and refinement and corresponds to the general lyrical character of the music piece. The greatest artistic complexity for button accordion performers in «Serenade» is precisely the embodiment of the character of a work that requires a certain level of student's artistic development, an open emotionality. «Harpsichord» is a work that helps to restore the picture of the aristocratic salon of the times of Rococo, but at the same time it gives certain tasks for the young performer. V. Vlasov somewhat unusually interprets the distribution of textural functions in this musical piece: the part in the left hand imitates the sound of a 
harpsichord, creating a harmonic accompaniment, while the soloing art of the right hand reflects the timbre of flute or oboe; here the coordination of the hands of the button accordionist and the differentiation of the strokes are important. The last music piece of the book «Watercolour» seems more complicated in content, and more complex in texture development and performance tasks. In this musical creation of this genre of painting, the composer redefines the established notions about the art technique of watercolors and combines the traditions of musical Impressionism with the elements of the «plot», which is represented as a picture. The Viktor Vlasov work, one of the most prominent representatives of the Ukrainian Button accordion School, is a special page of the musical culture of Ukraine and an important component of children's button accordion music. The most important achievement of the composer in the "Album for Children and Youth" is the systematic, consistent, professional justification of the whole set of musical and auditory ideas and professional skills that make this cycle can be a real school of button accordion craftsmanship.

Key words: ukrainian button accordion for children, album for children and youth, modern button accordion performance, V. Vlasov's composer style.

Постановка проблеми. Творчість Віктора Власова, одного 3 найяскравіших представників сучасної баянної школи України, є особливою сторінкою музичної культури i, зокрема, вагомою складовою баянного мистецтва для дітей. Своєю творчістю В. Власов впроваджує у вітчизняну дитячу музику нові ідеї та прийоми виконавської майстерності, які спираються на яскраві художні образи. Митець прицільно застосовує новітні композиторські техніки та приділяє увагу нетрадиційним прийомам звукоутворення у баянному виконавстві. Завдяки такому розмаїттю твори В. Власова слугують не лише своєму основному завданню - вихованню дітей, але i орієнтиром для інших композиторів. Втім музична наука й досі не надала належної оцінки творчості майстра, не виробила основні критерії його підходу до формування професійних навичок юного баяніста, не узагальнила стильові риси мислення.

Баянна музика українських авторів для дітей, яка складає значний пласт творів для юних виконавців, ще не була предметом грунтовних спеціальних досліджень. I хоча історія баянного виконавства та педагогіки порівняно з іншими музичними інструментами дуже коротка, можна стверджувати про формування певних шкіл баянної майстерності, у тому числі - авторських шкіл, до однієї з яких ми 
відносимо оригінальну творчість В. Власова. Його великий досвід виконавця, педагога, композитора та науковця знайшов відображення в циклі п'єс «Альбому для дітей та юнацтва».

Аналіз останніх публікацій за темою дослідження. У фундаментальних дослідженнях М. Булди [1], М. Давидова [3], А. Душного [4], С. Іванова [5], А. Сташевського [11], Д. Кужелєва [9] питання баянного виховання для дітей переважно розглядаються побіжно іншій проблематиці. Так, у монографії А. Сташевського, що присвячена дослідженню тенденцій розвитку жанрів сучасної української музики для баяна та акордеона, міститься перелік дитячих сюїт (дитячих альбомів), однак без необхідного аналізу та оцінки цього жанру [11]. В. Салій дослідив методичне забезпечення роботи над музичним образом у процесі навчання підлітків гри на баяні (акордеоні) та зупинився на сутності художнього образу музики, визначив його структурні компоненти з огляду на специфіку музично-виконавської діяльності [10].

О. Кметі висвітлює в одній із статей останнього часу репертуарні ${ }^{1}$ тенденції початкових мистецьких навчальних закладів України кінця XX-початку XXI століть, де поряд з іншими згадується «Альбом для дітей та юнацтва» В. Власова [8]. Дидактичні аспекти дитячої музики львівських композиторів (Я. Олексів, О. Колосовська, Е. Мантулєв, А. Онуфрієнко, В. Шлюбик, А. Нікіфорук, В. Балик, В. Салій, П. Серотюк) розглядає А. Душний [4] і зосереджується на «Альбомі для дітей та юнацтва», однак лише в ракурсі суто педагогічної проблематики. Дослідник відносить В. Власова до представників львівської баянної школи, грунтуючись на тому, що композитор навчався у Львівській державній консерваторії ім. М. В. Лисенка.

Аналіз особливостей формування дитячого репертуару баяністаакордеоніста на матеріалі творів В. Власова здійснила М. Булда, зосередившись переважно на його програмних і естрадно-джазових п’єсах [1]. Отже, пропонований аспект аналізу обраного матеріалу для розкриття проблеми дитячої баянної музики ще не був предметом музикознавчих зацікавлень.

1. Визначення музики для дітей лише як «репертуар» дещо знижує художню цінність цих творів. 
Об’єкт статті - баянне мистецтво для дітей; предмет формування системи професійних навичок баяніста-початківця у школі виконавської майстерності В. Власова.

Мета статті - виявити творчі настанови та системні засади формування музичного мислення баяніста на прикладі «Альбому для дітей та юнацтва» В. Власова.

Виклад основного матеріалу. Музика для дітей є специфічною та відповідальною сферою композиторської діяльності, вагому частину якої складає духовне й естетичне виховання молоді. Навчання музиці впливає на здатність дитини сприймати навколишній світ, вражати красою музичних звуків та відтінків, охоплювати різні жанри та стилі. Зокрема, Д. Кабалевський відзначав здатність дітей сприймати, запам'ятовувати та відтворювати досить складну музику, за умов, якщо ця музика яскрава, образна і природна у своєму розвиткові [6]. Дійсно, без художнього забарвлення музичного твору навіть найпростішу музику діти ніколи не сприймуть і не запам'ятають, оскільки вона не зворушить їхніх сердець та не вплине на їхню свідомість. До цього ж додамо, що юні виконавці-баяністи не тільки можуть сприймати таку музику, але і виконують іiі на високому рівні майстерності, що свідчить про засвоєння учнями складних засобів музичної виразності.

З поміж різноманітних явищ музичної культури баянна музика для дітей вирізняється своєю самобутністю, затребуваністю і популярністю. Перші кроки юних баяністів - складний та відповідальний період навчання. Саме на початковому рівні важливо поетапно розширювати музичні інтереси дитини, вміло при цьому підібрати твори для збагачування її слухового досвіду. Це безперечно стосується загальної стратегії музичного виховання, оскільки існує, як відмічав В. Клін, поетапне і загальнохудожнє виховання та спеціальне навчання, яке забезпечує планомірне осягнення мистецтва від найпростіших і уніфікованих до найскладніших і різноманітних його проявів та форм. Тому, вказує автор, «...дитяча музична література $є$ основним засобом залучення дитини та юнаків до світу дорослого мистецтва» (переклад наш) [7, с. 351].

В Україні період розвитку баянної музики для дітей був синхронізований зі становленням професійної баянної музики взагалі. 
Починаючи з другої половини XX ст. композитори-баяністи зробили величезний внесок у музичну спадщину творів для дітей. Водночас, відомості про цю сторінку музичної культури досі малодосліджені: недостатньо визначено потенціал українського дитячого баянного мистецтва, не узагальнена й не систематизована інформація щодо збірок п’єс для дітей та юнацтва українських композиторів. Сучасне дитяче баянне виховання, що є органічною частиною баянного мистецтва в цілому, в повній мірі відображає не тільки необхідні стадії формування навичок, але і самий шлях, яке пройшло це мистецтво від свого зародження (напівпрофесійний етап - 3 першої половини XIX століття) до академізації баянного мистецтва [12].

Музика для дітей охоплює безліч індивідуальних композиторських стилів (М. Лисенко, В. Косенко, Л. Ревуцький, В. Подвала, М. Сільванський, І. Шамо) та сучасних циклів, створених композиторамибаяністами. Серед них - імена К. Мяскова, В. Подгорного, О. Назаренка, А. Гайденка, В. Зубицького, А. Білошицького, В. Власова, П. Губанова, Е. Мантулєва, Б. Мирончука, Я. Олексіва, О. Шмикова. Поряд 3 цим у педагогічній практиці використовуються авторські «Школи гри на баяні», що побудовані за своєю стратегією (під редакцією С. Чапкія, А. Онуфрієнко, М. Різоля, А. Семешка, П. Серотюка та ін.). До композиторів з яскраво індивідуальним почерком, безумовно, слід віднести і В. Власова, який синтезує досягнення декількох баянних шкіл України: Львівської - де він навчався у консерваторії та Одеської - де і донині працює на посаді професора вже багато років.

В. Власов своєю багатопрофільною творчістю увиразнює тип музиканта-універсала - виконавця, композитора, педагога та науковця. Він удостоєний звання лауреата всеукраїнського конкурсу на кращий твір для українських народних інструментів (1977), є членом спілки композиторів України (1992), кінематографістів України (1991), заслуженим діячем мистецтв України (1996). За роки педагогічної роботи підготував велику кількість баяністів, які стали лауреатами національних і міжнародних конкурсів (А. Серков, А. Берсан, I. Комлєв, С. Брикайло, Р. Некрасов, А. Санжак, Г. Муращенко та ін.). Поряд 3 цим, В. Власов є автором багатьох творів для баяну: як складних, орієнтованих на виконання майстрами вищого рівня, так і для 
початківців. Багато з цих творів звучать у програмах баянних конкурсів, деякі включені в навчальні програми, хрестоматії, антології літератури для учнів початкових мистецьких закладів та професійних училищ. Творчість композитора тісно пов'язана з українською та світовою класикою, використанням аутентичного фольклору. Цінним $€$ те, що В. Власов особисто передає досвід у своїй науково-методичній роботі².

Окрім маштабних віртуозних творів ${ }^{3}$ доробок митця містить «Альбом для дітей та юнацтва», який став важливим здобутком у сфері баянного мистецтва. Цикл складаэться з 45 різнохарактерних п’єс, що не пов'язані між собою сюжетно-тематичною лінією: кожна має свій жанрову стилістику. П'єси згруповані в П'ять зошитів відповідно до загального задуму і чітко поставленому педагогічному завданню:

- «Альбом першокласника»-12 мікро п’єс для початківців;

- «У гості до казки» - 12 п’єс для учнів музичної школи;

- «Камерні твори»- шість різнохарактерних п’єс;

- «Народні мелодії» - шість п'єс на основі фольклору;

- «Естрадно-джазові п’єси» - дев'ять.

«Альбому для дітей та юнацтва» В. Власова притаманне світосприйняття стильової палітри через програмні моделі (через

2. Йому належать дослідження: «Исполнение полифонических призведений на баяне», «Способы исполнения штрихов на баяне», «Народное исполнительство - профессиональные традиции», «Виконавська інтерпретація джазових стилів на баяні», «О творческой деятельности И. А. Яшкевича», «Становление баянной композиторской школы в Украине», «Школа джаза на баяне и аккордеоне», «Методика роботи баяніста над поліфонічними творами».

3. Три концерти для баяна $(1964,1965,1973)$, Соната-експромт на буковинські теми для баяна та ударних інструментів; камерні твори, концертний триптих на тему картини Ієронима Босха «Страшний суд», «Скерцо-концертіно» для балалайки 3 камерним оркестром (2012), «Джаз-концертіно» для домри 3 камерним оркестром» (2013), фантазії та обробки народних мелодій, эстрадноджазові мініатюри для баяна (більше 30 творів), сюїта «П'ять поглядів на країну ГУЛАГ», «Концерт баян-бенд для баяну і джазового оркестру» (2014), «Джазконцертіно» для бандури з камерним оркестром (2015) та багато ін. 
засвоєння фольклору, жанрів академічної і сучасної музики). Саме в «Альбомі для дітей та юнацтва» В. Власов започатковує тенденцію послідовного і систематичного поєднання різних витоків баянної музики - фольклору, академічних принципів, естрадно-джазового музикування (сучасного модерну). При цьому композитор не уникає в першому та другому зошитах типових образів дитячої програмності (у назвах багато імен казкових героїв, назв іграшок, забав чи сюжетних перипетій $)^{4}$.

У зошитах є і неприхована звукозображальність, звуконаслідування, сценки з натури, однак не менш дієвим чинником конкретизації змісту слугує барвисте, рельєфне і динамічне втілення фольклорних жанрів. Про свій задум лаконічно, максимально точно висловився композитор на творчій зустрічі. Характеризуючи типи програмності у цих п’єсах для початківців, В. Власов вказував на різні джерела, в тому числі інтрамузичні жанри, сонористику [11]. ${ }^{5}$ Не менш важливим $€$ те, що саме на цій зустрічі композитор згадує свою роботу в кіно, підтверджуючи, що багато образів дитячого «Альбому для дітей та юнацтва» пов'язані з кінематографом (не випадково в одному із зошитів альбому є п’єса під назвою «Німе кіно»).

Більшість дослідників, що згадують «Альбом для дітей та юнацтва» В. Власова, звертають увагу переважно на твори перших розділів альбому, або ж на останній зошит (естрадно-джазові п’єси), що мають яскраву програмність та спираються на сучасну музичну мову. Однак не менш цікавим є центральний розділ «Альбому для дітей та юнацтва», який автор позначає як «Камерні п’єси». Авторська назва свідчить про те, що В. Власов хотів підкреслити більш узагальнений характер змісту зошиту на відміну від інших, хоча 3 широкої точки зору всі п’єси альбому є камерними.

4. Саме такі типи образності лежать в основі збірок «Дитячі сцени» Р. Шумана, «Дитячий альбом», П. Чайковського, «Дванадцять легких п'єс» С. Прокоф’єва, «Дитячий альбом» Б. Бартока та ін.

5. Творча зустріч з композитором Віктором Власовим відбулась в рамках IX міжнародного конкурсу баяністів-акордеоністів «Реrpetuum mobile». «Альбом першокласника» та «У світі казок» 3 «Дитячого альбому для дітей та юнацтва» виконував учень Роман Сапунцов (м. Черкаси), і сам композитор коментував його виконання, пояснював свої задуми та педагогічні цілі [11]. 
Чому автор звертається саме до такої назви? На нашу думку, композитор хоче абстрагуватись від конкретно-побутових жанрів і показати, що дитячі п’єси належать до академічної музичної традиції. 3 огляду на це, можна зробити висновок: цей зошит є справжньою скарбницею для виховання юних баяністів академічного спрямування. Композитор пропонує інший змістовний тип творчості, без якого професійне академічне мистецтво є неможливим.

Баянний репертуар до теперішнього часу опирається на традиції, запозичені від інших музичних інструментів: адже баян увібрав в себе певну «клавішну природу» фортепіано та «духову основу» органа. Завдяки цьому у баяна з'являється власний музичний голос. У зошиті «Камерні п’єси » В. Власов поєднав як жанрові (три сонатини), так і стильові зразки різних епох: від докласичного («Клавесин») - до імпресіонізму («Акварель»). Це важливо, оскільки баян не встиг накопичити за свою коротку історію достатню кількість оригінального репертуару, на відміну від фортепіано чи скрипки. Звідси створення умов, де учень знайомиться з академічним типом мислення, на наш погляд, $є$ дуже важливим. Особливо цінним є те, що знайомство 3 сонатною формою та жанром ліричної мініатюри відбувається на тих самих стилістично-мовних моделях, які були представлені в попередніх зошитах.

Три сонатини, що відкривають зошит «Камерні твори», сприймаються як невеликий цикл, де послідовно розкривається специфіка сонатного мислення і поступово ускладнюються художні та технічні завдання для виконавця. Перша мініатюрна «Сонатина» F-dur належить до ранньокласичного типу: без розробки, з полегшеною фактурою (переважає двухголосся, лише в кадансових зонах 3'являються тризвуки та септакорди). За авторським задумом нескладна фактура твору допомогає першому знайомству юного баяніста $з$ жанром сонати. Навіть у такому стислому викладі (всього 63 такта) представлено тематичний контраст і реалізовані функції сонатної форми. При цьому музична мова твору спирається на сучасний «інтонаційний словник».

Друга Сонатина D-dur відповідає зразкам віденських класиків: тематизм будується на основі похідного контрасту, в невеликій розробці вже присутнє мотивний розвиток. Цей процес підтримується активним 
гармонічними засобами і як результат - містить удавану репризу. Отже, цей твір потребує від юних виконавців не лише технічної підготовки, але й відповідного рівня музичного мислення.

Третя Сонатина (C-dur), найбільш складна за виконавським завданням, спирається на комплекс виразних засобів, відповідних музиці XX ст.: токатна основа тематизму, ускладнена гармонічна мова. До технічних складнощів варто віднести швидкий темп, артикульоване легато, ламані терції шістнадцятих у партії лівої руки з додержанням загального метро-ритму, уміння диференціювати фактурні плани у побічній партії в експозиції. Отже, три сонатини -це ніби "конспект" жанру для початківців-баяністів.

Наступні п’єси присвячені іншим жанрам, де основна увага автора приділяється перевтіленню стилістичних ознак. Так, інструментальна «Серенада» об'єднує декілька жанрових моделей, які відносяться до ліричної сфери. Так, у першому розділі в партії правої руки кантилена в одноголоссі «монтується» далі з імітацією хорового співу в акордовій фактурі. Супровід у лівій руці розвивається під впливом романтичних пошуків у фортепіанній фактурі: тут присутнє приховане двоголосся, а варіантність до того ж дозволяє змінювати гармонічну фігурацію в першому реченні на ритмічну у другому.

У кульмінації партії правої руки спостерігається ущільнення фактури, а фігурації в лівій руці охоплюють більш широкий діапазон. Найбільша художня складність для баяністів під час виконання «Серенади» полягає у втіленні характеру твору, що потребує художнього рівня розвитку учня, емоційності та володіння відповідними засобами виразності (агогікою, ритмічною пластикою, фразуванням, глибоким легато). Всі ці навички необхідні сформованому молодому виконавцю для втілення романтичного характеру музики.

«Клавесин». Назва твору говорить про те, що композитор намагається викликти у виконавця та слухачів асоціацію $з$ широко відомим старовинним інструментом. 3 XVII століття клавесин часто використовувався в камерній музиці не лише як солюючий інструмент, а й для виконання акомпонуючої функції. В цьому криється основне художнє завдання даної п'єси: створення обставин епохи рококо, коли в аристократичних салонах у виконанні ансамблів звучала така музика. Саме так В. Власов трактує у цій п’єсі розподіл фактурних 
функцій. Партія у лівій руці імітує звучання клавесину, створюючи гармонічну фігурацію акомпанементу, а солююча партія у правій руці відображає тембр флейти або гобоя. Саме це створює додаткові труднощі для виконавця, оскільки потрібно відтворити різні тембри музичних інструментів і різне по техніці звукоутворення (стакатний короткий, імітуючий щипкову техніку клавесину акомпанемент та інший - наспівне соло, зі своєю мелодичністю, мелізматикою та характером звучання, подібного духовому інструменту.)

Заключна п’єса зошиту «Акварель» здається більш складною за змістом, а відповідно - за фактурним розвитком та виконавським завданням. Як відомо, акварель - це техніка у образотворчому мистецтві, що дозволяє створювати ефект легкості, тонкості у художніх переходах. У музичному втіленні цього жанру композитор дещо переосмислює усталені уявлення про техніку акварелі і використовує барви, які здаються дещо незвичними. В. Власов поєднує традиції музичного імпресіонізму 3 елементами «сюжету», який нібито намальований на картині: тобто екстрамузичний тип програмності (образотворчий) з інтромузичним. Такий підхід зближує метод В. Власова з французькими імпресіоністами (про це свідчить, наприклад, фактура першого розділу). У верхньому регістрі «порожні» квартоквінтові співзвуччя на тлі застиглих акордів, іноді з підголосками, що пожвавлюють звучання. В подальшому мікрофактурне проростання наче відображає власне процес малювання акварелі, прояснення фону 3 новими відтінками.

Середній розділ п'єси контрастує: це вже сфера моторики, ніби мультиплікаційний прийом, коли на тлі пейзажу відбувається якась дія. 3 точки зору розуміння форми п'єси виконавцю варто підкреслити контраст розділів, а з іншого боку - зберегти відчуття єдиного процесу «творення» акварелі аж до динамічної репризи. В репризі тричастинної форми продовжується ущільнення фактури - нанесення від самого початку шарів на прозору основу всього твору. Складність п’єси полягає у втіленні узагальнено-програмного задуму автора. Його реалізація вимагає подолання численних художніх та технічних складнощів, довершеного володіння інструментом. Баяністи зустрінуться з багатоголоссям різного типу (акордового викладення, 3'єднання диференційованих ліній) та різноманітною ритмікою, 
витонченою динамікою. Всі виконавські параметри потребують чіткості виконання, максимальної напруги в загальній кульмінації, володіння фразуванням у мелодичній лінії.

Висновки. Постать В. Власова - композитора, педагога, виконавця - $€$ знаковою в баянній музиці для дітей другої половини XX століття. Географія творчої діяльності В. Власова об'єднує практично всю Україну (від Білгород-Дністровській музичної школи та Львівської консерваторії та Одещини). Митець багато років відвідує з лекціями та майстер-класами інші регіони України: від Дрогобичадо Харкова. Композиторська діяльність В. Власова сприймається в нерозривній єдності з його власними концертно-виконавськими досягненнями та педагогічними дослідженнями. Завдяки такій універсальній діяльності композитору вдалось втілити в «Альбомі для дітей та юнацтва» чітку стратегію загально-музичного виховання 3 метою досягнення професійної майстерності. У своєму альбомі автор спирається на принцип «від простого - до складного». 3 перших п’єс зошиту юним баяністам пропонується виборна клавіатура, чим забезпечується рівномірний розвиток обох рук виконавця i розширюються можливості для оволодіння різними фактурними прийомами у лівій руці для більш повноцінного втілення музичного образу творів.

Створивши «Альбом для дітей та юнацтва» частково на народнопісенній основі, а частково - із застосуванням сучасної музичної мови, автор жадав залучити якомога більше дітей до джерел музики та навчити їх художньо-образному сприйманню з раннього віку («Альбом першокласника» та «У гості до казки»). На цій основі побудовано і подальше виховання юних музикантів-баяністів, але вже на більш у професійному грунті. Однією з важливих рис, притаманних стилю композитора, $є$ поєднання у творах професійних здобутків європейської музики з невичерпним інтонаційним багатством українського мелосу. Про це свідчить влучна оцінка «збірного стилю» В. Власова, надана Д. Кужелєвим: «...його багатоскладовий стиль - це своєрідна «мовна дисперсія», урізноманітнення образно-стильових моделей на основі плюралістичного бачення навколишнього світу» [9, с. 93]. Найголовніше досягнення композитора у «Альбомі для дітей та юнацтва»- системне, послідовне впровадження всього комплексу 
професійних музично-слухових уявлень та навичок, завдяки чому його можна вважати школою баянної майстерності.

Перспектива подальшого дослідження теми. Окреслене проблемне поле може бути ектрапольоване на інші явища баянної творчості для дітей, як в аспекті загального музичного виховання, так і в плані системності навчання юних баяністів принципам композиторського мислення. Перспективним здається також порівняння історичних умов розвитку дитячого баянного мистецтва з процесами становлення інших інструментальних шкіл (фортепіанної, духової, гітарної).

\section{Література}

1. Булда М. В. Особливості формування дитячого репертуару баяністаакордеоніста (на матеріалі творів В. Власова). Вісник КНУКіМ. Мистецтвознавство : зб. наук. пр. К., 2012. №27. 229 с.

2. Власов В. П. Альбом для дітей та юнацтв. Одеса, 1999. 57 с.

3. Давидов М. А. Історія виконавства на народних інструментах (Українська академічна школа): підручник. Київ : НМАУ імені П.І.Чайковського, 2005. 418 c.

4. Душний А. I. «Дитячий альбом» як основа дидактичного репертуару у доробку представників Львівської баянної школи. Українська культура: минуле, сучасне, шляхи розвитку: зб. наук. пр: наукові записки Рівненського державного гуманітарного університету: в 2-х т. Вип. 17. Рівне: РДГУ, 2011. T.1. C. 257-262.

5. Іванов Є. Українське академічне баянно-акордеонне мистецтво. Проблеми еволюції. Феномен школи в музично-виконавському мистецтві : тези міжнар. наук.-теорет. Конф. (Київ, НАМУ ім. П. Чайковського, 22-23 бер. 2005) [ред.упор. М. Давидов, В. Сумарокова]. К., 2000. С. 33-34.

6. Кабалевський Д. Б. Як розповідати дітям про музику. Київ : Музична Україна, $1982.320 \mathrm{c}$.

7. Клин В. Л. О музыке. Киев : Музична Україна, 1985. 351 с.

8. Кметі О. Репертуарні тенденції початкових мистецьких навчальних закладів України кінця XX - початку XXI століть: баянно-акордеонний аспект. Актуальні питання гуманітарних наук. 2014. Вип. 8. С. 122-128.

9. Кужелєв Д. О. Баянна творчість сучасних українських композиторів у контексті сучасних стильових тенденцій. До 70-річчя кафедри народних інструментів Київської консерваторії (НМАУ) імені П. І. Чайковського: зб. наук. ст. [ред.-упор. М. Давидов]. К. : НМАУ, 2010. С. 91-101. 
10. Салій В. С. Методика роботи над музичним образом у процесі навчання підлітків гри на баяні (акордеоні) : автореф. дис. ...канд. пед. наук : 13.00 .02 «Теорія та методика муз. навчання». Нац. пед. ун-т імені М. П. Драгоманова. K., $2010.23 \mathrm{c}$.

11. Сташевський А. Я. Великі жанри в українській музиці для баяна. Монографія. Луганськ: Поліграфресурс. 159 с.

12. Тищик В. Б. Розвиток баянного мистецтва для дітей в Україні: історичні передумови та сучасні тенденції. Вісник Харк. держ. академ. дизайну і мистецтв. Сер. мистецтвознавство : зб. наук. пр. Х., 2017. №4. С. 131-136.

\section{References}

1. Bulda M. V. Osoblyvosti formuvannia dytiachoho repertuaru baianistaakordeonista (na materiali tvoriv V. Vlasova) [Special features of the childish repertoire of bayan_sta-akordeonista (on materials by V. Vlasov)]. Visnyk KNUKiM. Mystetstvoznavstvo : zb. Nauk. Pr. K.,2012. №27.

2. Vlasov V. P. Albom dlia ditei ta yunatstva [Album for children and youth]. Odesa, $1999.57 \mathrm{~s}$.

3. Davydov M. A. Istoria vykonavstva na narodnyh instrumentah (Ukrainsjka akademichna shchkola): pidruchnyk [History of Viconau on popular instruments (Ukrainian School): pidruchnik]. Kyiv : NMAU imeni P. I. Chaikovsjkogo, 2005. 418 s. 4. Dushnyi A. I. «Dytiachyi albom» yak osnova dydaktychnoho repertuaru u dorobku predstavnykiv Lvivskoi baiannoi shkoly ["Children's Album" yak is the basis of the didactic repertoire at the entrance to the Lviv Bayan School]. Ukrainska kultura: mynule, suchasne, shliakhy rozvytku: zbirnyk naukovykh prats: naukovi zapysky Rivnenskoho derzhavnoho humanitarnoho universytetu. U 2-kh t. Vyp. 17. Rivne: RDHU, 2011. T. 1. S. 257-262.

5. Ivanov E. Ukraiinsjke akademichne bajanne-akordeonne mystetstvo. Problemy evoljutsii [Ukrainian Academy accordion accordion-accordion mystic. Problems evolyutsi]. Fenomen shkoly v muzychno-vykonavsjkomu mystetstvi: tezu miznar. nauk.-teoret. konf. (Kyiv, NAMU imeni. P. Chajkovskogo, 22-23 ber. 2005) [red.upor. M. Davydov, V. Sumarokova]. K., 2000. C. 33-34.

6. Kabalevskyi D. B. Yak rozpovidaty ditiam pro muzyku [How to tell children about music]. Kyiv. : Muzychna Ukraina, 1982.320 s.

7. Klin V. L. O muzuke [About music]. Kyev. :Muzychna Ukraina. 1985.351 s.

8. Kmeti O. Repertuarni tendentsii pochatkovykh mystetskykh navchalnykh zakladiv Ukrainy kintsia XX pochatku XXI stolittia: baianno-akordeonnyi aspect [Repertoire tendencies of elementary artistic educational institutions of Ukraine of the end of the XX - the beginning of the XXI centuries: accordion-accordion aspect]. Aktualni pytannia humanitarnykh nauk. 2014. Vyp. 8. S. 122-128. 
9. Kuzheliev D. O. Baianna tvorchist suchasnykh ukrainskykh kompozytoriv u konteksti suchasnykh stylovykh tendentsii [The Bayan creativity of contemporary Ukrainian composers in the context of contemporary stylistic tendencies]. Do 70richchia kafedry narodnykh instrumentiv Kyivskoi konservatorii (NMAU) imeni P. I. Chaikovskoho: zb. nauk. st. [red.-upor. M. Davydov]. K.: NMAU, 2010. S. 91101.

10. Salii V. S. Metodyka roboty nad muzychnym obrazom u protsesi navchannia pidlitkiv hry na baiani (akordeoni) [Method of work on the musical image in the process of training teenagers playing the accordion (accordion)]: avtoref. dys. ...kand. ped. nauk : 13.00.02 «Teoriia ta metodyka muz. navchannia». Nats. ped. un-t im. M. P. Drahomanova. K., 2010. 23 s.

11. Stashevskyi A. Ya. Velyki zhanry v ukrainskii muzytsi dlia baiana [Great genres in Ukrainian music for bayan]. Monohrafiia. Luhansk: Polihrafresurs. $159 \mathrm{~s}$.

12. Tyshchyk V. B. Rozvytok baiannoho mystetstva dlia ditei v Ukraini: istorychni peredumovy ta suchasni tendentsii [The development of bayana arts for children in Ukraine: historical background and current trends]. Visnyk Khark. derzh. akadem. dyzainu i mystetstv. Ser. Mystetstvoznavstvo : zb. nauk. pr. Kh., 2017. №4. S. 131-136. 